\title{
APPROPRIATION OF PUBLIC URBAN SPACE AS AN EFFECT OF PRIVATISATION AND GLOBALISATION
}

\author{
Lidia MieRZEJEWSKA \\ Adam Mickiewicz University, Institute of Socio-Economic Geography and Spatial Management, Poznań, \\ Poland
}

Manuscript received June 14, 2011

Revised version October 28, 2011

\begin{abstract}
MieRZEJEWSKA L., Appropriation of public urban space as an effect of privatisation and globalisation. Quaestiones Geographicae 30(4), Bogucki Wydawnictwo Naukowe, Poznań 2011, pp. 39-46. DOI 10.2478/v10117-011-0036-7, ISBN 978-83-62662-88-3, ISSN 0137-477X.
\end{abstract}

AвSTRACT. The changes taking place in the public space of many cities of the world have been assessed as harmful. They are seen as resulting from modern processes shaping their spatial-functional structure. Among them are advancing privatisation, which leads to various forms of public space appropriation, and globalisation, which transforms the world from a world of cities and places into one of networks (especially the Internet and motorways). In Polish cities, however, the deterioration in the quality and accessibility of public spaces is due not only to the social awareness developing in the conditions of neoliberalism and a market economy, which puts private property above public to get over the experience of feasible socialism, but to some extent also to Polish legislation. The aim of this article is to present forms and ways of appropriation of public urban space in the conditions of privatisation and globalisation, as well as reasons why this development seems to intensify in the Polish conditions.

KEY WORDS: public space, appropriation of public space, privatisation of public space

Lidia Mierzejewska, Institute of Socio-Economic Geography and Spatial Management, Adam Mickiewicz University, ul. Dzięgielowa 27, 61-680 Poznań, Poland; e-mail: mierzeja@amu.edu.pl

\section{Introduction}

The changes taking place in the public space of many cities in the various parts of the world have been assessed as harmful. They are seen as resulting from modern processes shaping their spatial-functional structure. Among them are advancing privatisation, which leads to various forms of public space appropriation, and globalisation, which transforms the world from a world of cities and places into one of networks (especially the Internet and motorways). The discussion on the subject in the literature usually expresses concern about threats to public urban space and places significant to residents as well as tourists and business people visiting them, impoverished interpersonal relations, degradation of spatial order, and a socio-cultural and economic degradation of the entire city (Kopel 2009).

Over the last 20 years, also the public space of Polish cities has changed and diversified significantly. In the Polish conditions, however, this is thought to be a consequence not only of the above-mentioned factors, but also of Polish 
society trying to get over the trauma of feasible socialism when the rights of an individual, including his right to freedom and property, came second to the rights of the community (Parysek 2005, Dymnicka 2008). In Poland's new reality, it is private property that is a superior value. This tendency to put private property above public is due not only to the social awareness developing in the conditions of neoliberalism and a market economy, but to some extent also to Polish legislation. As a result, one can observe an advancing fragmentation of public space, which is often a conglomerate of discontinuous functions, a set of loosely connected fragments, while the problem of various forms of public space appropriation grows worse and worse (cf. Harvey 1985, Jałowiecki 2007a, Dymnicka 2008).

This study is a theoretical one, and its basic aim is to elucidate the specific nature of public property, the notion and importance of public spaces, forms and ways of appropriation of public urban space in the conditions of privatisation and globalisation, as well as reasons why this development seems to intensify in the Polish conditions.

\section{Public space and its understanding}

Public space is commonly understood to involve physical accessibility. This kind of space consists primarily of roads and streets, city squares, and various permanently accessible facilities and buildings in public ownership. Access to a public space is open to every individual, with no additional conditions imposed from without. Hence, it is a shared space in which social interactions connected with the satisfaction of various social needs take place in accordance with the system of values held in the given society (cf. Kowalczyk 2009). Those interactions may manifest themselves in disputes (various types of conflict or confrontation), but also in cooperation. Public space understood in this way is always an effect of the community that modifies it, but also of an impact by individuals (cf. Habermas 1989, Kowalczyk 2009).

It is usually assumed, also in Polish society, that it is necessary to have clear rules separating public from private space, which stems from the liberal conception by John Stuart Mill. In his essay On liberty, he asserted that the private sphere involves the freedom of an individual (the individual's right to act) and a space that allows this freedom to be exercised. The public sphere involves legally sanctioned, ordered and agreed upon actions by others, making the practice of social life efficient, with individuals aware of how they are to behave and act, and communities recognising and obeying the accepted rules, which implies a loss of a measure of liberty, but in return ensures safety and permanence of the negotiated order (Mill 1859, after Kowalczyk 2009).

Also in the neoliberal theory proposed by Rawls (1993) the private is clearly distinguished from the public, the public being connected with the state established as a result of a social contract; it assumes the form of political measures determined in legal terms, with special place given to the principle of justice. To Rawls, the public sphere should be neutral and minimise the possibility of appropriation of even a part of individual freedom, which could happen if particularist interests should come to the fore. Thus, universal values should be employed in creating public space, such as liberty, equality before the law, justice, the quality of life, pluralism, and world-view neutrality (Rawls 1993, after Kowalczyk 2009).

In sociology, a similar point of view is taken by Held (1986), who believes that public space is a place where individuals should be assured liberty and the equality of choice of the conditions of their own lives, naturally if those conditions do not infringe on the rights of other individuals. In such a public space citizens are aware of their rights and duties, are active politically and socially, and engaged not only in pursuing their own particularist interests, but are also sensitive to the needs and aspirations of others, so that "each voice shall be heard" (Held 1986, after Kowalczyk 2009).

In reality, however, the division of space into private and public is not that clear-cut. Distinguished in the latter is also a quasi- or pseudopublic type of space which does not fully meet the requirements set for public space because of restrictions and limitations imposed on its use (cf. Zastawniak et al. 1994). This category of space embraces both, land and facilities in public own- 
ership (state, municipal or communal property), like fenced-in parks and gardens or public utility buildings, and private property like the halls of shopping centres and cinemas, marketplaces, or car parks, which the owner or manager opens to the public in a specified time interval. In this way some of the private space also turns into a public space, which can be treated as a continuum of space as well as of public and private activity (cf. Mitchel \& Staeheli 2009, Maik 2011).

In Poland, public urban space is shaped in accordance with the provisions of the Physical Planning and Spatial Development Act of 2003. In its understanding, a public space is an area, delineated in a commune's Study of the Conditions and Directions of Spatial Development, which is of special significance in that it helps to satisfy the needs of the residents, improve the quality of their lives, and encourage social contacts owing to its location and functional-spatial characteristics. However, the Act does not list concrete categories of public space and leaves many other issues unclear, for example what social contacts the legislators had in mind. Presumably, not those established by football hooligans at a stadium, or the link between a mugger and his victim in a dark alley or park, but social interactions that accord with the system of values observed in the given society (cf. Lipiec 2009, Kowalczyk 2009).

The statutory understanding of public space also seems rather physical, or even technical. Space is not three-dimensional here, but a fragment of an area delineated in the study. Moreover, worth stressing is the fact that a city is a much more diversified area, with a whole lot of elements which do not meet either the statutory or the informal definition of public space, but which, being adjacent to traditionally understood public space, contribute to its quality.

Also, the statutory definition ignores the landscape aspect, so strongly emphasised by urban planners, for example in the Public Space Charter, as decisive for a city's identity and the quality of life of its residents. Thus, the understanding of public space in Polish legal acts is rather narrow, and the procedures for shaping it, especially those employed in planning practice, wrong. Further details can be found in Jędraszko (2007), Buczek (2011), Mierzejewska (2011), Parysek (2006), and others.
In the mentioned Public Space Charter adopted in 2009 at a congress of Polish Urban Planners in Poznań, public space is defined as "a special space in common use which is a product of civilisation irrespective of the form of ownership, and its public character follows from the way it is used". Thus, public space is not only an area belonging to a local government, but also the part of an area managed by other entities that contributes to a city's landscape, climate and aesthetics. For the Charter authors, public space means primarily areas accessible to all, together with elements of nature, land development and construction found in those (public) areas as well as in the space above them, in their neighbourhood, and in the range of vision of people present there. Such a public space, intentionally designed by man in accordance with social rules and values, the Charter authors claim, is itself the highest value determining a city's identity and a resource of strategic importance for the local community. As such, it needs special care and protection. It should also be moulded and used in accordance with the rules set in the Charter, demanding suitable attitudes and right measures to be adopted by public space managers, i.e. primarily local authorities, but also local communities.

In accordance with the Charter provisions, the local authorities should primarily: (1) ensure access to public space and create such spatial forms which minimise exclusion and the appropriation of space (like e.g. in gated communities), (2) protect the existing social and spatial structures, valuable urban objects and layouts, as well as traditions of a place and the local culture, and (3) protect social diversity, for example by protecting the interests of weaker social groups (Public Space Charter 2009).

Thus, in the light of the Charter, an important instrument in shaping public urban spaces is physical planning, but in the Polish conditions this domain leaves a lot to be desired.

\section{The fall or a transformation of public spaces?}

The unfavourable changes taking place in public urban space have prompted many authors to proclaim its fall. However, it is an open ques- 
tion whether we are justified to speak of the fall of public space, or rather of its transformation occurring under the influence of new tendencies, such as privatisation and globalisation.

The changes in the character and function of public urban spaces go basically in two directions (Maik 2011):

1) from a space of communication promoting direct talk to a space of consumption where a crowd of individuals seek to satisfy their consumer needs, and

2) from an open space, accessible to all citizens, to a space with limited access, exhibiting a tendency to 'close'.

In both cases this leads to its shrinkage or disappearance, and to gradual deterioration in its quality and accessibility (Bauman 2000, Maik 2011). Areas that traditionally used to be public spaces increasingly turn into private ones (the privatisation of public space). One can observe an advancing fragmentation of public space, which often forms a conglomerate of discontinuous functions, a set of loosely connected fragments, hardly related with the city (Harvey 1985, Jałowiecki 2007a, Dymnicka 2008).

The fragmentation of public urban space is seen as springing mainly from the rate and dynamics of change in social life, but also from a crisis of big-city mass society (MikułowskiPomorski 2006). Among its manifestations are: (1) poor social awareness of the importance of the common good for the state and its citizens, (2) the wrong belief that a free market will be able of itself (without public intervention) to balance the spatial and the socio-economic type of development, (3) priority of individual interests over the common good, especially in physical planning and spatial development, and (4) insufficient participation of society in deciding about socio-economic and spatial development (Public Space Charter 2009). Of no little significance is also the homogenisation of everyday life in a city as a result of modern city-planning solutions, the development of suburbs as a sign of predominance of private interests over public ones, and a change in the lifestyle manifesting itself, e.g., in giving up a life in the town square (by choice or necessity) in favour of the 'charms' of television (Maik 2011). In modern cities one can observe the disappearance of communities, while a citizen participating in political and social life is being replaced by a citizen-consumer (Nawratek 2008, after Maik 2011). In the process of dispersal of functions, places and people, an important role is played by new 'city users', primarily corporate entities and business people with their powerful impact on the transformation and organisation of the city and its landscape (Sassen 1999).

The city is also being transformed by advanced information technology, with the changes following various patterns depending on the context (historical, territorial and institutional) (Castells 1996, Sassen 1999, Jałowiecki 2007b, Dymnicka 2008). A similar view is expressed by Gregotti (2005), who claims that some changes of urban space brought about by the new technologies developing so dynamically in the era of globalisation can have a tremendous effect on a city's layout, while the idea of urban marketing wins against the vision of a diversified (well-balanced) city. He also observes that the population increasingly tends to make use of cities rather than to inhabit them (Gregotti 2005, after Wrana 2010).

It clearly follows from the above reflections that public urban space keeps changing, the changes primarily induced by the privatisation and globalisation of many aspects of socioeconomic life. In the Polish conditions, to those general world tendencies one should add insufficient awareness of the importance of public spaces, a mismatch between the development of those spaces and the requirements of modern city residents, and the weakness of physical planning. As a result, local authorities surrender the right to mould the living space of residents of a concrete commune to individual investors and developers, which is an alarming tendency. "If cities withdraw from public space - by selling, i.e. privatising, it - they in fact pursue (...) a (neo)liberal élitist programme of 'you want safety, you buy it'. (...) The withdrawal of cities from the public sphere, the privatisation of cities and urban space, is thus not just an aesthetic problem; it is a social catastrophe and a political crime" (Nawratek 2005, after Kopel 2009: 162163). Thus, one cannot but agree with the statement that what we need most urgently today is an institution protecting public space (Bauman 2007, after Kopel 2009). 


\section{Appropriation of public space}

One of the fundamental problems of public urban spaces is their appropriation, also called usurping appropriation, understood as seizing someone else's rights to something (Kwiatkowski 2010). The usurping appropriation of space, according to Kwiatkowski (2010), consists in its being taken over more or less illegally, sometimes even symbolically. This procedure embraces a vast range of measures, from quite innocent to very harmful, even leading to erosion of entire communities. Kwiatkowski proposes the following classification of usurping measures:

1) functional usurpation, consisting in the appropriation of public spaces by private investors in the form of e.g. private spaces of public hypermarkets and shopping centres, housing estates, etc.,

2) cultural usurpation, manifesting itself in the appropriation of the premises of housing estates by the subculture of football hooligans, and

3) quasi-criminal and criminal usurpation, embracing such activities as aggravated battery and killings by members of the usurping communities of football hooligans operating on concrete estates, through youth gangs to a division of a city into zones of influence of individual criminal organisations.

The class in which the local authorities responsible for the moulding of public urban spaces have a direct say is the first one, viz. functional usurpation. This class will now be considered in greater detail with reference to hypermarkets and shopping centres, gated communities, as well as motorways and expressways cutting the city area.

\subsection{Hypermarkets and shopping centres}

There is no doubt that in modern cities huge, brightly lit hypermarkets and shopping centres have taken over the functions of the marketplace. "They have become locales to which we make "pilgrimages» in order to practice our consumer religion" (Ritzer 1999: x). By comparison, other, traditional public spaces are often perceived as old-fashioned, which may stem from lack of awareness of their role in the spatial structure of the city and of their contribution to the quality of life of its residents.

Kwiatkowski (2010) believes that hypermarkets and shopping centres are not only an important category of public (or in fact quasi-public) space, but that they also appropriate it through:

- private investors taking over fragments of public space,

- use of this space being governed, among others, by a $4 \mathrm{~F}$ rule, or 'forget your car, forget the street, forget services, forget yourself', which is a metaphor of shopping centres closing to the outside world, and

- limiting the time of use.

However, one cannot fully support this opinion, because the implementation of a city's shopping/service function has always required the allocation of a specific space to it and has always implied a limited time of use. This applies equally to land and facilities in private ownership (such as large-volume stores) and to public property (public buildings, public administration, etc.). But the statement one can certainly agree with is that the location of this type of facilities on city margins contributes to uncontrolled expansion of the built-up area (i.e. urban sprawl), which greatly determines a city's functional-spatial structure (Kwiatkowski 2010).

It is also worth mentioning that hypermarkets and shopping centres show a huge demand for space which they often use in an extensive way (e.g. large-lot car parks filled only on days before a holiday rather than underground or multi-level facilities), which cannot be assessed as good in terms of social rationality.

\subsection{Gated communities}

It is generally accepted that the phenomenon of closed, fenced-in housing estates was practically absent until the early 1990s, although in the global cities of Latin America it could be observed as early as the 1970s. Today, however, it has grown to be so common in the cities of both, developing and highly advanced states that it has been termed global and become an object of much research and analysis (Czerny 2011). It is assumed that the increase in the closed-off ('privatised') areas in cities 
is an effect of growing criminal rates and threats felt by residents of particular districts and housing estates. The argument of improvement in safety standards is often used by developers (Czajka \& Sobolewski 2010). However, there also appear opinions that this process is driven by growing social polarisation and a wish to emphasise one's social status as expressed, among other things, by living in a protected, monitored district, often offering its 'own' public spaces, etc. (Glasze, Webster \& Frantz 2006, after Czerny 2011). The popularity of gated communities results primarily from the idea of privatisation, which is an impulse for economic and political decisions supporting the construction sector, but lack of political stability is of no little significance here, too (Czerny 2010, 2011).

In the case of gated communities, the appropriation of space involves mainly (Kwiatkowski 2010, Czerny 2011, Czajka \& Sobolewski 2010, Wicher 2010):

- restriction of public access (spatial isolation), which is against the rules of modern urban planning,

- elimination of citizen involvement, disappearance of socially oriented activities and an atomisation of the residents, also owing to a deficit of places that would encourage social contacts,

- increase in the spatial segregation and homogenisation of the estate community, or the fact that the estate residents are of similar social status (adhere to similar values and have similar incomes) while those who might bring down the level of safety are excluded, and

- creation of spatial barriers, the effects including traffic jams (some streets are closed and so unable to reduce congestion).

Gated communities, ever more popular because of security and the architectural aesthetics, seem attractive, but only from an individual rather than a social perspective. Putting a stop to estate gating can be considered one of the challenges facing city authorities in various regions of the world.

\subsection{Motorways and expressways}

An important category of public space is roads and streets, presumably including also intra-city motorways. The definition of a motorway implies that it is a limited access road, for use by specified types of motor vehicles only. While the definition does not state it explicitly, by assumption this road is supposed to link various places. This, however, is determined not only by its route, but primarily by entrance and exit roads that supplement it. Motorways and expressways, as well as other infrastructural elements like airports, harbours, railway stations, etc., connect large cities into a global network, thus becoming accelerators of economic development. At the local scale, however, they are often seen as 'dissecting the city', disrupting close neighbourhood spaces (and the nearness of residents), and hampering intra-urban communication.

Motorways and expressways appropriate public space primarily through (cf. Kopel 2009):

- occupying large, open spaces,

- creating spatial barriers hard to penetrate not only for people, but also for animals,

- restricting public access (only vehicles that meet specified conditions, often user charges),

- extending and complicating many people's daily journeys from their places of residence to a nearby town, school, workplace, recreation place, etc.,

- spatially separating neighbourly communities on the two sides of the road, thus making social contacts difficult,

- generating needs in the field of mobility and transport, and

- decentralising the population, thus intensifying the processes of suburbanisation and urban sprawl.

So many detrimental consequences of motorways are obviously no argument for giving up their construction where they are needed, but in each case the route of this type of road must be very well thought out, taking into consideration not only the economic calculus, but also social and natural aspects. The technological solutions applied should be well thought-out, too, in order to eliminate as far as possible the above disadvantages of having a high-speed road.

At this point it is worth reminding Giddens' (2005) postulate that city streets should be made not only safe, but also full of life, because arterial roads, despite their fast car traffic, are not. 
Thus, a formidable challenge facing modern cities is to balance the competition between networks (motorways, the Internet, etc.) and places significant for the residents (Castells 2003, Kopel 2009).

\section{Conclusion}

Privatisation and globalisation are processes which affect many aspects of socio-economic life, including public space, thus influencing a city's spatial-functional structure and the quality of life of its residents.

Public space is primarily a responsibility of local authorities, which should conduct a spatial management policy intended to ensure city residents wide access to public space, minimise the exclusion and appropriation of space, protect social diversity, and represent the interests of the weaker social groups.

However, the changes occurring in the public space of cities, also Polish, are assessed as unfavourable, as they involve fragmentation, commercialisation and, first of all, appropriation of public space. In Poland this tendency has for years been prompted by an imperfect law and poor spatial management in communes. A change in management policy is especially required for public space in residential places because, if exempted from the need to observe suitable standards, it will still be pegged to only one index (of significance to the developer): use rate of a plot's area (Wicher 2010).

Many forms of public space appropriation can be distinguished. One of them is functional usurpation, whose effect is change in the spatialfunctional structure of cities. Among the factors responsible for the change is the construction of hypermarkets and shopping centres on city margins, gated communities, as well as intra-city roads and motorways. Functional usurpation is one of the causes of increased dynamics of such undesirable processes as urban sprawl and social segregation. Therefore all possible steps should be taken to stop the harmful processes going on in the public spaces of many cities because those spaces, once lost through functional appropriation, will be hard to recover in the future.

\section{References}

Bauman Z., 2000. Globalizacja. I co z tego dla ludzi wynika (Globalisation. And what this implies for people). Państwowy Instytut Wydawniczy, Warszawa.

Bauman Z., 2007. Płynne życie (Liquid life). Wydawnictwo Literackie, Kraków.

Buczek G.A., 2011. Przestrzeń publiczna a jakośćżycia izamieszkiwania (Public space and the quality of life and living places) (http:// www.urbanistyka.info/ node/2080/1956; accessed 20 June 2011).

Castells M., 1996. The rise of the network society. Blackwell, Oxford.

Castells M., 2001. The Internet galaxy: Reflections on the Internet, business and society. Oxford University Press, Oxford.

Czajka R. \& Sobolewski A., 2010. Atrakcyjność środowiska zamieszkania $\mathrm{w}$ aspekcie dostępności przestrzeni publicznej (Attractiveness of the living environment in terms of accessibility of public space). Architektura. Czasopismo Techniczne, 5 (2-A). Wydawnictwo Politechniki Krakowskiej.

Czerny M., 2010. Twórcy i aktorzy przestrzeni miejskiej $\mathrm{w}$ wielkich aglomeracjach globalnego Południa (Creators and actors of urban space in large agglomerations of the global South). In: Madurowicz M. (ed.), Wartościowanie wspótczesnej przestrzeni miejskiej. Wydawnictwo WGSR Uniwersytetu Warszawskiego/Urząd MiastaStołecznego Warszawy, Warszawa: 273-286.

Czerny M., 2011. Prywatyzacja przestrzeni publicznej w mieście - przykłady z krajów Ameryki Łacińskiej (Privatisation of public urban space: Examples from Latin American states). In: Marciniak K., Sikora K. \& Sokołowski D. (eds), Koncepcje i problemy badawcze geografii. Wydawnictwo Uczelniane Wyższej Szkoły Gospodarki w Bydgoszczy, Bydgoszcz: 147-160.

Dymnicka M., 2008. Fragmentaryzacja przestrzeni publicznej - próby rekompozycji (Fragmentation of public space: Attempts at recomposition). Studia Regionalne i Lokalne, 3(33): 33-52.

Giddens A., 2006. Sociology (fifth edition). Polity, Cambridge.

Glasze G., Webster C. \& Frantz K., 2006. Private cities: Global and local perspective. Routledge, Abingdon, Oxon.

Gregotti V., 2005. L'urbain au futue: continuites et discontinuites. The 49th International Federation for Housing and Planning World Congress, Rome 2-5 October 2005: 10-11.

Habermas J., 1989. The structural transformation of the public sphere. MIT Press, Cambridge, Mass.

Harvey D., 1985. Consciousness and the urban experience. Studies in the history and theory of capitalist urbanization. Blackwell, Oxford.

Held D., 1986. Models of democracy. Stanford University Press, Stanford.

Jałowiecki B., 2007a. Fragmentacja i prywatyzacja przestrzeni (Fragmentation and privatisation of space). In: Jałowiecki B. \& Łukowski W. (eds), Gettoizacja polskiej przestrzeni miejskiej. Wydawnictwo Naukowe Scholar, Warszawa.

Jałowiecki B., 2007b. Globalny świat metropolii (The global world of metropolises). Wydawnictwo Naukowe Scholar, Warszawa.

Jędraszko A.B., 2007. Europeizacja gospodarki przestrzennej w Polsce - zarys propozycji założeń nowej ustawy (Europeanisation of spatial management in Poland: An outline of assumptions of a new legal act). Kwartalnik 
Naukowy Instytutu Rozwoju Miast. Problemy rozwoju miast, 1-2: 66-101.

Karta Przestrzeni Publicznej (Public Space Charter), 2009. Towarzystwo Urbanistów Polskich i Związek Miast Polskich (http://www.tup.org.pl/download/2009_0906_ KartaPrzestrzeniPublicznej.pdf; accessed 20 June 2011).

Kopel J., 2009. Zarzadzanie - racjonalność a etyczność (Management - rationality versus ethics). Oficyna Wydawnicza Humanitas, Sosnowiec.

Kowalczyk J., 2009. Paradygmaty zmian w przestrzeni publicznej kobiet (Paradigms of change in the public space of women). Teka Komisji Politologii i Stosunków Międzynarodowych - OL PAN, 4: 18-28.

Kwiatkowski K., 2010. Przestrzeń publiczna i jej uzurpatorskie zawłaszczanie (Public space and its usurping appropriation). Architektura. Czasopismo Techniczne, 6 (2-A). Wydawnictwo Politechniki Krakowskiej.

Lipiec P., 2009. Przestrzeń publiczna, prywatna czy społeczna (Space: public, private or social) (http://lipiec.waw. $\mathrm{pl} / 380$ / przestrzen-publiczna-prywatna-czy-spoleczna; accessed 20 June 2011).

Maik W., 2011. Ewolucja miejskich przestrzeni publicznych: od agory do świątyni konsumpcji (Evolution of urban public spaces: from the agora to a cathedral of consumption). In: Mierzejewska L. \& Wdowicka M. (eds), Wspótczesne problemy rozwoju miast i regionów. Bogucki Wydawnictwo Naukowe, Poznań (in press).

Mierzejewska L., 2011. Przestrzeń publiczna strefy podmiejskiej (na przykładzie Poznania) (Public space of the suburban zone: The case of Poznań). In: Mierzejewska L. \& Wdowicka M. (eds), Wspótczesne problemy rozwoju miast i regionów. Bogucki Wydawnictwo Naukowe, Poznań (in press).

Mikułowski-Pomorski J., 2006. Fragmentaryzacja jako proces ponowoczesny. Rekompozycja poprzez fragmentaryzację (Fragmentation as a postmodern process. Recomposition through fragmentation). Euro-limes 1(6) (www.euro. limes.ae.krakow.pl; accessed 20 June 2011).

Mill J.S., 1859. On liberty (1999, O wolności. Akme, Warszawa).

Mitchell D. \& Staeheli L.A., 2009. Public space. In: Kitchin R. \& Thrift N. (eds), International encyclopedia of human geog- raphy. Elsevier, Amsterdam, Boston, London, New York: 511-516.

Nawratek K., 2005. Ideologie w przestrzeni. Próby demistyfikacji (Ideologies in space. Attempts at de-mystification). Wydawnictwo Universitas, Kraków.

Nawratek K., 2008. Miasto jako idea polityczna (The city as a political idea). Korporacja Halart, Kraków.

Parysek J.J., 2005. Miasta polskie na przełomie XX i XXI wieku. Rozwój i przeksztatcenia strukturalne (Polish cities at the turn of the 21st century. Development and structural changes). Bogucki Wydawnictwo Naukowe, Poznań.

Parysek J.J., 2006. Wprowadzenie do gospodarki przestrzennej (An introduction to spatial management). Wydawnictwo Naukowe UAM, Poznań.

Physical Planning and Spatial Management Act of 27 March 2003. Official Gazette, no. 80, position 717, with later amendments.

Rawls J., 1993. Political liberalism. The John Dewey Essays in Philosophy, 4. Columbia University Press, New York.

Rewers E., 2005. Post-polis. Wstęp do filozofii ponowoczesnego miasta (Post-polis. An introduction to the philosophy of the postmodern city). Wydawnictwo Uniwersitas, Kraków.

Ritzer G., 1999. Enchanting a disenchanted world. Pine Forge Press, New York.

Sassen S., 1999. Globalization and its discontents: Essays on the new mobility of people and money. New Press, New York.

Wicher W., 2010. Witalność przestrzeni publicznej (Vitality of public space). Architektura. Czasopismo Techniczne, 6 (3A). Wydawnictwo Politechniki Krakowskiej.

Wrana J., 2010. Rewitalizacja przestrzeni publicznej drogą do integracji lokalnej (Public space revitalisation as a road to local integration). Architektura. Czasopismo Techniczne, 6 (3-A). Wydawnictwo Politechniki Krakowskiej.

Zastawniak B., Podolakowa E., Tomlinson G., Clarke P., Barret E. \& Jedge E., 1994. Miejscowe planowanie przestrzenne (Local physical planning). In: Gospodarka przestrzenna gmin. Poradnik. T. III. Miejscowe plany zagospodarowania przestrzennego. Brytyjski Fundusz KnowHow - Fundusz Współpracy, IGPIK, Kraków: 1-119. 